\title{
LEISURE TIME ACTIVITIES AND MENTAL HEALTH AMONG IRAN OLDER PEOPLE: A POPULATION-BASED STUDY IN TEHRAN

\author{
${ }^{1}$ Seyedeh Mahboubeh Hosseini Zare \\ ${ }^{2}$ Maryam Tajvar \\ ${ }^{3}$ Nahid Dehghan Nayeri \\ ${ }^{4}$ Abbas Rahimi Foroshani \\ ${ }^{5}$ Ahmad Ali Akbari Kamrani \\ ${ }^{6}$ Ahmad Siar Sadr \\ ${ }^{{ }^{7}}$ Abolghasem Pourreza
}

\begin{abstract}
Background: Leisure activity helps the elderly to improve their physical and mental health. The purpose of this study is to determine the interlink between leisure activity and mental health in older people.

Methods: We select 413 people over 60 years old(213 female and 200male). We collected data using GHQ 15-question survey, Nagi questionnaire, and a new reliable and validated the designed questionnaire. We analyzed our data utilizing spearman correlation, and regression analysis in SPSS21.

Results: We report a relationship between recreational and religious activities in the absence of confounding factors but only religious activities were associated with mental health in the presence of confounding factors(p-value $<0 / 0001)$. Among the confounding factors, physical health imposed the most significant effect.

Conclusion: Considering the determinative effect of physical health on the types of leisure activity, and the significant relationship between the types of the elderly's leisure activity and their mental health, having comprehensive planning in the physical health in older people is necessary.
\end{abstract}

Keywords: mental health; physical health; leisure;activities; aged;Iran

Received $12^{\text {th }}$ February 2019, accepted $05^{\text {th }}$ June 2019, published $09^{\text {th }}$ June 2019

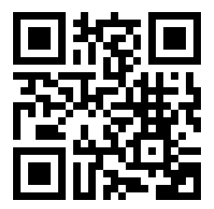

www.ijphy.org

10.15621/ijphy/2019/v6i3/183875

\footnotetext{
${ }^{1} \mathrm{PhD}$ student in Health Care Management, School of Public Health, Tehran University of Medical Sciences, Tehran, Iran. Email: hosseinizare@uswr.ac.ir

${ }^{2}$ Assistant Professor, Department of Health Management and Economics School of Public Health, Tehran University of Medical Sciences, Tehran, Iran. Email: mtajvar@sina.tums.ac.ir ${ }^{3}$ Professor, School of Nursing and Midwifery, Tehran University of Medical Sciences, Tehran, Iran. Email: nahid.nayeri@tums.ac.ir ${ }^{4}$ Professor, Department of Epidemiology and Biostatistics, School of Public Health, Tehran University of Medical Sciences, Tehran, Iran. Email: rahimifo@tums.ac.ir

${ }^{5}$ Associated professor, Iranian research center on aging. University of Social Welfare and Rehabilitation Sciences, Tehran, Iran. Email: akbarikamrani@uswr.ac.ir

${ }^{6} \mathrm{PhD}$ student in Information Technology Management,School of Management, Islamic Azad University of Central Tehran Branch. Tehran, Iran.Email:ahmad.sadr@sharif.edu
}

\section{CORRESPONDING AUTHOR}
${ }^{{ }^{*}}$ Abolghasem Pourreza
Professor,Department of Health Management and Economics School of Public Health, Tehran University of Medical Sciences, Tehran, Iran. E-mail:abolghasemp@tums.ac.ir 


\section{INTRODUCTION}

The world average age is going up, and the world is undergoing a population transaction process. In the process reduces mortality in the community and increases the life expectancies. In this way, the age structure of the population from the young group changes to the elderly group [1]. United nation (UN(describes the old community as the one with rather than $7 \%$ of elderlyover 60 years old [2]. Based on the census conducted in 2016, 9.3\% of the Iranian population, 7.3 million people, is older than 60 years, which means Iran is considered as an old country. The predictions indicate that $30 \%$ of the Iranian population will be over 60 years by 2050 [3].

Physical and mental activities significantly decrease in the old ages, and so older people 's ability to engage in leisure activities reduce also [4]. Our definition of leisure time is the time that the person is not in charge of any duties and responsibilities and can spend his/her time upon his/her preferences [5]. The elderly have more leisure time after their retirement compares to other age groups. Also, the elderly consider this time as a reward after years of work, which allows them to reach self-esteem, and creativity, mental and physical health by engaging in leisure activities [6].

Since retirement, income reduction, loneliness, loss of a spouse, lack of social support, children independency and ultimately decline in physical and mental health, having comprehensive planning for their leisure activities will protect them from lots of expressed issues.

Many studies revealedthe importance of leisure timeactivities on the elderly's mental health [7,8,9]. Lee et al. (2018) study showed that participating in leisure activities decreased the chance of having depression in the elderly [10]. Also, the study conducted by Heeschet al. (2012)calculated the older adult's physical activity at three-timeparts and resulted in a certain relation among the amount of acting and mental health [11].

Similarly, longitudinal and cross-sectional studies found positive affiliation between certain kinds of social activities, like going to the theater and reading magazines, and mental health status among middle age and elderly [12, 13]. Wada et al. (2007) showed that Japanese people with regular leisure activates in their 20s to 70 s less suffer from depression symptoms [14]. Similarly, Wakui et al. (2012) showed that performing leisure activity once per week reduces the depression rate among middle-aged and elderly [15]. The investigationwas done by Li and Ferraro (2005) also showed that involving in regular voluntary activity improves mental health status on people aged 60 and over [16].

However, Eslami et al. (2002) did not find any relation between the students 'depression and the type of leisure activity [17]. Hazarjaribi and Arfaee (2011), however, showed that leisure and social activities in young people, 15 to 29 years old, improve their social health [18].

The pattern of leisure activity effects on the quality and joys of life, which is not limited to individual lives, but improves the society quality of life. To retain and enhance the elderly's physical and mental health, we need to involve them more in social activities such as leisure activities[19].

The survey aims to determine the effect of types of leisure activity like recreational, sports, social interactions, arts, cultural events, and religious activities, on the elderly's mental health. In the study, we controlled the effect of confounding factors like age, gender, socioeconomic factors, and physical health on our analysis.

\section{METHODS}

In this study, the Cross-Sectional method has been taken advantage of. Our including criteria were as follow: 1) above 60 years old; 2) Mentally stable and normal; 3) Lack of physical disability that adversely affects their routine life; 4) Existence of communication skills that enabled them to answer the questioners willingly.

For the sampling method, the random cluster sampling has been executed as will discussas following:Tehran has been sectioned to 5 different geographical zones: North, South, East, West, and Center. Then, in each zone, one municipal district from 22 has been selected randomly. After that, the list of the all intersections which are close to the residential area has been prepared, and one intersection has been chosen randomly as the main cluster. Then, by considering the population of the cluster, the proper amount of samples has been taken among the households. Eventually, 430 elderly citizens have participated in the study.

Questioners have been trained for sampling and face to face interview with citizens in a session. The objective of the study has been discussed to the citizens and questionnaires have been distributed among them after each expression of his/her willingness to participate in the study.

The questionnaires have been completed by interview. For any reason, if anyone has not been ready to participate in the study, they skipped from the survey and the next household had been involved in the study. If there were more than one eligible person in a household to participate in the study, all of them had participated in the study.

The tools used in the study included demographic information, the questionnaires for leisure time spent, and physical and mental health.

The used leisure activity questionnaire is obtained by conducting a quality study on leisure activity. In the study, we included people on age of 60 and older in Tehran. We included the people who were willing to involve in the study and were not suffering from serious physical and mental issues. The included people had a different educational level and came from different social and geographical regions. Twenty-one people got involved in the interview. The obtained questionnaire contains eight categories, including recreation, sports, social interactions, relaxation, article activities, cultural activity, media, and religious practices. Since the nature of the questions was different, and the answers were not transparent, we number coded the answers, as one indicated yes and 2 was the indicator of No. The val- 
idation of the questionnaire was assessed by Content Validity Ration (CVR) and the Content Validity Index (CVI), and thereliability was evaluated by Split Half method, the obtained correlation index was 0.72 .

The mental health was studied using GHQ 15-question questionnaire. The questions were number coded by applying Lickert method ranged from 0 to 4 . And the total score in the questionnaire was 45[20]. The validity of the Persian version of the questionnaire was approved by JahadDaneshgahi medical research institute. Cronbach's alpha was determined as 0.77 to 0.9 [21].

For evaluation of the physical health, we used the Nagi questionnaire [22]. The Nagi questionnaire is part of the SF36 questionnaire, which contains ten questions that were number coded by Licker method that is indicated by numbers 1,2 , and 3 . The validity and reliability of the questionnaire were approved by previous studies.

In the study, we used descriptive statistical analysis in SPSS ver 21 . The dependent and independent variables in this study were the mental health status and leisure activity. In the descriptive analysis of the study we assessed the demographical situations, leisure time activities, and mental health of the elderly.

In the inferential statistical analysis, we used the Spearman correlation to assess the relationship between the elderly's leisure activities and their mental health. Also, we used the regression equation to evaluate the simultaneous effect of different categories of leisure activities on mental health. The confounding factors in the survey were: gender, age, marital status, educational and financial situation, and physical health.

\section{RESULTS}

Among the initial 430 elderly included in the study, 17 questionnaires were excluded due to the questionnaire incompletion.

In the study, women have outnumbered men by 13 , and $49.7 \%$ of the population were in age between 63 to 70 years. $72.1 \%$ of the included population was married; however, among them, $88.7 \%$ of women were a widow. $44.8 \%$ of the population were either illiterate or with low educational level, and $68.7 \%$ of the population had a middle-class life (Table 1).

Table 1: Demographic characteristic of the elderly

\begin{tabular}{|c|c|c|c|c|}
\hline \multirow{3}{*}{\multicolumn{2}{|c|}{$\begin{array}{l}\text { Demographic character- } \\
\text { istic }\end{array}$}} & \multicolumn{3}{|c|}{ sex } \\
\hline & & female & male & Total \\
\hline & & $\begin{array}{c}\text { number } \\
\text { (Percentage) }\end{array}$ & $\begin{array}{c}\text { number } \\
\text { (Percentage) }\end{array}$ & $\begin{array}{c}\text { number } \\
\text { (Percentage) }\end{array}$ \\
\hline \multirow{3}{*}{ Age(years) } & $60-62$ & $58(14.0)$ & $48(11.6)$ & $106(25.6)$ \\
\hline & $63-70$ & $104(25.1)$ & $102(24.6)$ & $206(49.7)$ \\
\hline & $71-95$ & $51(12.3)$ & $50(12.1)$ & $101(24.4)$ \\
\hline \multirow{3}{*}{$\begin{array}{l}\text { Marital } \\
\text { status }\end{array}$} & Married & $115(27.8)$ & $183(44.3)$ & $298(72.1)$ \\
\hline & $\begin{array}{l}\text { Single, Sepa- } \\
\text { rated }\end{array}$ & $19(4.6)$ & $7(1.6)$ & $26(6.2)$ \\
\hline & Widowed & $79(19.1)$ & $10(2.4)$ & $89(21.5)$ \\
\hline
\end{tabular}

\begin{tabular}{|c|c|c|c|c|}
\hline \multirow{3}{*}{$\begin{array}{l}\text { Number of } \\
\text { children }\end{array}$} & 0 & $9(2.17)$ & $2(0.4)$ & $11(2.5)$ \\
\hline & $1-4$ & $124(30.02)$ & $148(35.8)$ & $272(65.8)$ \\
\hline & $5-10$ & $80(19.3)$ & $50(12.1)$ & $130(31.4)$ \\
\hline \multirow{4}{*}{$\begin{array}{l}\text { Arrange- } \\
\text { ments of } \\
\text { life: }\end{array}$} & single & $50(12.1)$ & $6(1.4)$ & $56(13.5)$ \\
\hline & $\begin{array}{l}\text { Only with the } \\
\text { spouse or }\end{array}$ & $58(16.2)$ & $83(20.1)$ & $141(36.3)$ \\
\hline & $\begin{array}{l}\text { With spouse } \\
\text { and children }\end{array}$ & $56(13.5)$ & $100(24.2)$ & $156(37.7)$ \\
\hline & $\begin{array}{l}\text { Living with } \\
\text { children or } \\
\text { others }\end{array}$ & $49(11.8)$ & $11(2.6)$ & $60(14.4)$ \\
\hline \multirow{5}{*}{ Education } & Illiterate & $47(11.3)$ & $13(3.1)$ & $60(14.4)$ \\
\hline & Elementary & $67(16.2)$ & $59(14.2)$ & $126(30.4)$ \\
\hline & $\begin{array}{c}\text { Middle } \\
\text { School-High } \\
\text { School }\end{array}$ & $40(9.5)$ & $33(7.9)$ & $73(17.5)$ \\
\hline & Diploma & 41 (9.9) & $57(13.8)$ & $98(23.7)$ \\
\hline & $\begin{array}{c}\text { Master.Doc- } \\
\text { torate }\end{array}$ & $18(4.3)$ & $38(9.2)$ & $56(13.5)$ \\
\hline \multirow{5}{*}{$\begin{array}{l}\text { Current } \\
\text { Job }\end{array}$} & Free job & $7(1.6)$ & $33(7.9)$ & $40(9.5)$ \\
\hline & Shopkeeper & $3(0.7)$ & $28(6.7)$ & $31(7.4)$ \\
\hline & housekeeper & $160(38.7)$ & $2(0.4)$ & $62(39.1)$ \\
\hline & Retired & $36(8.7)$ & $120(29.0)$ & $56(37.7)$ \\
\hline & Employee & $7(1.6)$ & $17(4.1)$ & $24(5.7)$ \\
\hline \multirow{3}{*}{$\begin{array}{c}\text { Financial } \\
\text { Status }\end{array}$} & Good & $46(11.1)$ & $46(11.1)$ & $92(22.2)$ \\
\hline & medium & $150(36.3)$ & $133(32.2)$ & $283(68.5)$ \\
\hline & weak & $17(4.1)$ & $21(5.0)$ & $38(6.1)$ \\
\hline \multirow{2}{*}{$\begin{array}{l}\text { Financial } \\
\text { aid }\end{array}$} & no & $200(48.4)$ & $192(46.4)$ & $392(94.8)$ \\
\hline & yes & $13(3.1)$ & $8(1.9)$ & $21(5.0)$ \\
\hline \multirow{3}{*}{$\begin{array}{c}\text { Housing } \\
\text { Status }\end{array}$} & personal & $170(41.1)$ & $163(39.4)$ & $333(80.6)$ \\
\hline & leased & $29(7.0)$ & $23(5.5)$ & $52(12.5)$ \\
\hline & others & $14(3.3)$ & $14(3.3)$ & $28(6.6)$ \\
\hline \multirow{3}{*}{$\begin{array}{l}\text { Housing } \\
\text { area }\end{array}$} & $\begin{array}{c}\text { Less than } 50 \\
\text { meters }\end{array}$ & $9(2.1)$ & $15(3.6)$ & $24(5.7)$ \\
\hline & $\begin{array}{l}\text { Between } \\
50 \text { and } 100 \\
\text { meters }\end{array}$ & $132(31.9)$ & $111(26.8)$ & $243(58.7)$ \\
\hline & $\begin{array}{l}\text { More than } \\
100 \text { meters }\end{array}$ & $72(17.4)$ & $74(17.9)$ & $146(35.3)$ \\
\hline
\end{tabular}

The results showed that 408 people (98.8\%) watched TV in their leisure time. Three hundred ninety-one people (94.7\%) spent their leisure time by calling their friends and relatives. Only 26 people (6.3\%) exercised in their leisure time and 28 people $(6.8 \%)$ played. The statistical analysis showed that media has the leading role in addressing the elderly's leisure activity (84.01\%), which was followed by relaxation (77.96\%) and cultural activities (21.06\%).

To assess the mental status of the participants, we used GHQ-question type. In this method, the highest number is dedicated to the worst mental health status. $48 \%$ of participants experienced a headache in the past month. $65 \%$ of the elderly felt a lack of satisfaction in their lives (Table 2). 
Table 2 - Mental health questionnaire (GHQ)

\begin{tabular}{|c|c|c|c|c|}
\hline \multirow{2}{*}{ Question } & Not at all & $\begin{array}{l}\text { No more than } \\
\text { usual }\end{array}$ & $\begin{array}{l}\text { Rather more than } \\
\text { usual }\end{array}$ & $\begin{array}{l}\text { Much more than } \\
\text { usual }\end{array}$ \\
\hline & $\begin{array}{l}\text { Frequency } \\
\text { (Percentage) }\end{array}$ & $\begin{array}{l}\text { Frequency } \\
\text { (Percentage) }\end{array}$ & $\begin{array}{l}\text { Frequency } \\
\text { (Percentage) }\end{array}$ & $\begin{array}{l}\text { Frequency } \\
\text { (Percentage) }\end{array}$ \\
\hline 1- Did you experience any headache recently? & $16(40.0)$ & $10(2.4)$ & $38(9.2)$ & $198(47.9)$ \\
\hline 2- Did you experience difficulty of staying sleep recently? & $163(39.5)$ & $16(3.9)$ & $70(16.9)$ & $164(39.7)$ \\
\hline 3- Did you have anxiety related sleep difficulties recently? & $117(28.3)$ & $21(5.1)$ & $89(21.5)$ & $186(45.1)$ \\
\hline 4- Did you recently feel nervousness all the time? & $148(35.8)$ & $21(5.1)$ & $73(17.7)$ & $171(41.4)$ \\
\hline 5- Do the routine works take more time recently? & $128(31.0)$ & $14(3.4)$ & $75(18.2)$ & $196(47.5)$ \\
\hline Question & $\begin{array}{l}\text { More so than } \\
\text { usual }\end{array}$ & Same as usual & $\begin{array}{l}\text { Rathae less than } \\
\text { usual }\end{array}$ & $\begin{array}{l}\text { Much less than } \\
\text { usual }\end{array}$ \\
\hline 6- Did you recently manage to keep yourself busy and occupied? & $46(11.1)$ & $58(14.0)$ & $142(34.4)$ & $167(40.5)$ \\
\hline $\begin{array}{l}\text { 7- Did you feel recently that you are well capable of taking care of your } \\
\text { daily works? }\end{array}$ & $49(11.9)$ & $9(2.2)$ & $88(21.3)$ & $267(64.6)$ \\
\hline 8- Did you feel satisfied recently? & $45(10.9)$ & $10(2.4)$ & $76(18.4)$ & $282(68.3)$ \\
\hline 9- Did you feel useful recently? & $72(17.4)$ & $6(1.5)$ & $67(16.3)$ & $268(64.9)$ \\
\hline 10- Were you recently able to enjoy your normal day-to-day activities? & $49(11.9)$ & $16(3.9)$ & $85(20.6)$ & $263(63.7)$ \\
\hline \multirow{2}{*}{ Question } & Not at all & $\begin{array}{l}\text { No more than } \\
\text { usual }\end{array}$ & $\begin{array}{l}\text { Rather more than } \\
\text { usual }\end{array}$ & $\begin{array}{l}\text { Much more than } \\
\text { usual }\end{array}$ \\
\hline & $\begin{array}{l}\text { Frequency } \\
\text { (Percentage) }\end{array}$ & $\begin{array}{l}\text { Frequency } \\
\text { (Percentage) }\end{array}$ & $\begin{array}{l}\text { Frequency } \\
\text { (Percentage) }\end{array}$ & $\begin{array}{l}\text { Frequency } \\
\text { (Percentage) }\end{array}$ \\
\hline 12- Have you recently felt that life is entirely hopeless? & $292(70.7)$ & $8(1.9)$ & $27(6.5)$ & $86(20.8)$ \\
\hline 13- Did you recently feel that life isn't worth living? & $325(28.7)$ & $9(2.2)$ & $21(1.5)$ & $58(14.0)$ \\
\hline $\begin{array}{l}\text { 14- Did you recently feel so anxious that were not able to execute rou- } \\
\text { tine activity? }\end{array}$ & $215(25.1)$ & $10(2.4)$ & $39(9.4)$ & $149(36.1)$ \\
\hline 15 - Did you recently wish to be dead? & $335(81.1)$ & $14(3.4)$ & $19(4.6)$ & $45(10.9)$ \\
\hline
\end{tabular}

To assess the physical health status, we used the Nagi questionnaire. Our data showed that $42.1 \%$ of the elderly had physical limitation in jogging, lifting heavy things, and endurance exercise. Also, $24.7 \%$ of the participants faced difficulties in more simple activities like lifting vacuum machine and light exercises. 24\% could not use the stairs, and $22.3 \%$ of them experienced limitation on bending and kneeling. $14.8 \%$ of the elderly could not walk more than one block, and $7.3 \%$ of the people faced difficulties in taking a shower and getting dressed.

In the current study, since we were not dealing with normal numbers, we used the Spearman correlation to assess any relation between typed of elderly's leisure activities and their mental health. Besides media and relaxation, there was a meaningfulcorrelationbetween participates leisure activity and their general health.

We found a negative relationamong GHQ scores (the higher the score, the worst the GHQ) and cultural activities of the elderly, the correlation coefficient was observed as -0.164 . Therefore, if the GHQ score increased by 1 number, the cultural activity score dropped by 1 number (Table 3 ).
Table 3- The spearman correlation test based on the type of leisure activities

\begin{tabular}{|l|c|c|}
\hline \multicolumn{1}{|c|}{ Leisure activities } & r & sig \\
\hline Recreation & -0.258 & $0 / 000$ \\
\hline Sport & -0.236 & $0 / 000$ \\
\hline Social interactions & -0.163 & $0 / 001$ \\
\hline Rest & 0.032 & $0 / 510$ \\
\hline Art & -0.207 & $0 / 000$ \\
\hline Cultural activities & -0.164 & $0 / 000$ \\
\hline Media & -0.060 & $0 / 224$ \\
\hline Religious activities & -0.140 & $0 / 004$ \\
\hline
\end{tabular}

To assess the relationship between types of leisure activity and confounding factors like age, gender, marital status, educational and financial situation, and physical health on GHQ (mental health), we used multiple regression statistical analysis, which is represented in table 4 .

We excluded relaxation and media from our statistical analysis since we did not observe any relation between these factors and participant's mental health.

Considering the point that higher GHQ means pooper mental health, we obtained the following results: 
The first model is representing the multiple regression statistical analysis between categories of leisure activity and GHQ. In the absence of confounding factors, recreation and religious activities showed the most significant negative relationship with GHQ. The first model indicated more effect of religious activities on mental health than recreation.

The second model is representing the relation between species of leisuretime activity and mental health in the presence of confounding factors. The result shows that recreation has no longer Affective on GHQ. Physical health showed a modest effect among all confounding factors, Beta value $=-0.418$.

The third model shows the effect of volume of leisure timeon mental health in the absence of confounding factors. Here we show a correlation between volume of leisure time and GHQ.

The fourth model is representing the effect of volume of leisure time on GHQ in the presence of confounding factors. Although still there is a correlation between leisure time and GHQ, its effect dramatically decreased Beta=0.173 . Among the confounding factors, physical health showed the most effect, which was followed by economical and educational situation and age.

Table 4: Multiple regression representing the effect of types of leisure activities on GHQ

\begin{tabular}{|c|c|c|c|c|c|c|c|c|}
\hline \multirow{2}{*}{$\begin{array}{c}\text { Leisure } \\
\text { activities }\end{array}$} & \multicolumn{2}{|c|}{ Model 1 } & \multicolumn{2}{c|}{ Model 2 } & \multicolumn{2}{c|}{ Model 3 } & \multicolumn{2}{c|}{ Model 4 } \\
\cline { 2 - 9 } & Beta & sig & Beta & sig & Beta & sig & Beta & sig \\
\hline Recreation & -0.151 & 0.026 & -0.019 & 0.762 & - & - & - & - \\
\hline Sport & -0.075 & 0.231 & 0.002 & 0.973 & - & - & - & - \\
\hline $\begin{array}{c}\text { Social in- } \\
\text { teractions }\end{array}$ & -0.022 & 0.696 & -0.028 & 0.578 & - & - & - & - \\
\hline $\begin{array}{c}\text { Artistic } \\
\text { activities }\end{array}$ & -0.097 & 0.087 & -0.092 & 0.067 & - & - & - & - \\
\hline $\begin{array}{c}\text { Cultural } \\
\text { activities }\end{array}$ & -0.052 & 0.313 & -0.032 & 0.519 & - & - & - & - \\
\hline $\begin{array}{c}\text { Religious } \\
\text { activities }\end{array}$ & -0.117 & 0.015 & -0.099 & 0.024 & - & - & - & - \\
\hline $\begin{array}{c}\text { Volume of } \\
\text { Leisure }\end{array}$ & - & - & - & - & -0.351 & 0.000 & -0.173 & 0.000 \\
\hline gender & - & - & -0.060 & 0.223 & - & - & -0.055 & 0.258 \\
\hline $\begin{array}{c}\text { age } \\
\text { Marital } \\
\text { status }\end{array}$ & - & - & -0.034 & 0.479 & - & - & -0.027 & 0.569 \\
\hline $\begin{array}{c}\text { Education- } \\
\text { al level }\end{array}$ & - & - & 0.015 & 0.773 & - & - & 0.016 & 0.739 \\
\hline $\begin{array}{c}\text { Economic } \\
\text { status }\end{array}$ & - & - & 0.108 & 0.016 & - & - & 0.098 & 0.027 \\
\hline $\begin{array}{c}\text { Physical } \\
\text { health }\end{array}$ & - & - & -0.418 & 0.000 & - & - & -0.414 & 0.000 \\
\hline
\end{tabular}

\section{DISCUSSION}

In the current study, we assessed the relationshipsbetween the types of elderly's leisure activity and their mental health. The results showed a correlation between the volume of leisure activity and mental health in the presence and absence of confounding factors. Among the categories of leisure activity, the relation between recreation and religious activities was significant in the absence of confound- ing factors, but only religious activities were associated with mental health in the presence of confounding factors. Among the confounding factors, physical health imposed the most significant effect.

The results showed that $65.5 \%$ of the participants spent their leisure time by going to the local parks. Similar results have been observed in Madah et al. (2009) study, where they observed that going to the local park in the most common leisure activity among older adults in Iran [23]. Here we also observed that $77.2 \%$ of the participants go for a walk in their leisure time. Going for a walk was also observed as a common leisure activity among European elderly [24]. Since regular walk will help the elderly to recapture their muscle strength and is helpful for their heart function and so improve the elderly's quality of life [25], encouraging elderly for participating in walking can help improve their welfare [26]. Similar to our results, Cheung et al. (2009) showed a low inclination of older adults in participating in art and cultural activities [27]. However; Lee at al (2014) showed that art and cultural activities were the second common leisure activities among their studies population (26). Here we show that $43.1 \%$ of our participants study on their leisure time, which is very similar (34.2\%) to what Madah et al. (2009) have been reported [23]. However, Norouzi et al. (2006) observed the unwillingness of Iranian elderly to study on their leisure timeactivities [28]. Regarding the level of participants' education, we did not expect a strong inclination to study. Also, our data showed that $28.5 \%$ of the participants suffered from visual problems, which can be another explanation of our results. However, PailardAbaorg (2009) pointed study as the most common leisure activity among Swedish people, which could be because of the availability and affordability of books [29].

The results showed that $98.8 \%$ of the participants spend their leisure time watching TV. Conde et al. in 2012, and Hyun Lee in 2014 distinguished watching television as a most favorite leisure activity among Spanish and Korean older people, respectively $[30,26]$. Similar to the mentioned studies, Kent \& Stewart in 2007, Triado et al., in 2009, and Cheung et al., in 2009 founded watching TV as the most common leisure activity among Americans, European and Hong Kongese respectively [31,24, 27]. Considering the physical limitation of the elderly, one explanation for favorability of watching TV can be no need for physical activities.

We observed that $62 \%$ of our participants went to the mosque in their leisure time. Although Madah et al. observed similar results (64.7\%) in Iran, he found Swedish elderly not to be eager to go to sanctuary places (16.4\%) [23], which is suggesting the effect of culture on the elderly's leisure activities.

In our study, the participants should explain the reason for the lack of leisure activity. Results showed to reasons include lack of interest, inconvenience, lack of time, lack of transportation, illness, physical limitation, distance, illiter- 
acy, lack of awareness, loneliness, lack of partner, inconvenient environment, lack of space, and expenses.

Our results showed a positive correlation between the volume of leisure time and mental health in the elderly. Tessier et al. in 2007 also concluded the significant relationship between their population mental health and leisure activities [32]. Physical activity stimulates the release of neurotransmitters and neurotrophic factors, and so improve cognition and mental health [33]. We observed physical health as the most effective confounding factor among all confounding factors, which indicated the importance of physical health on the relation between leisure and mental health in the elderly.

The surveyresultsshowed that physical health is an effective factor in the relationamong leisure time and mental health of the elderly. The physical limitation of Iranian elderly is much higher than the world average [34], which not only worsen the elderly's mental health but can increase the incidence of physical illness and so lower life quality. Marquez's et al. in 2009 demonstrated the exercises and physical activities importance on the improvement of physical limitations [35]. The authorities awareness of the current situation, and cognizance of the elderly's difficulties and needs, and encourage the elderly to exercise are the most effective approaches tothe improvement of the elderly's mental health.

In the presence of disturbing factors, only religious activities were effective in mental health. Holstila et al. in 2018 showed that leisure activities with low physical activity demands imposed the most effect on the elderly's mental health [36]. Besides, participating in religious practice is an opportunity for the elderly to participate in social activities, which is helpful for mental health improvement.

We also reported that recreation and religious practices are effective in mental health in the absence of disturbing factors, which shows the importance of mosque and volunteer activities. Offering social activities, like recreational camps in the mosque, also can be another approach to improve the involvement of the elderly in social activities. Moreover, local government can be effective by scheduling group activities like chess and Ping-Pong competition in local parks and recreational centers, and city tour.

\section{CONCLUSION}

Considering the determinative effect of physical health on the types of leisure activity, and the significant relationship between the types of the elderly's leisure activity and their mental health, having comprehensive planning in the physical health in older people is necessary.

\section{Collaborations}

Hosseini Zare SM, Tajvar M, DehghanNayeri N, AkbariKamrani AA, and Pourreza A had a contribution to the project design, data collection, conception, article writing, critical review and final approval of the studyfor publishing. Rahimi Foroshani A and Sadr AS had a contribution to the data analysis and interpretation.

\section{REFERENCES}

[1] KavehFirouz Z. The study of the effect of socio-demographic structures on the elderly's quality of life in Tehran. Ph.D.thesis in Sociology, University of Tehran, Iran:2011.

[2] Dadkhah A. Review of aged rendered services in USA and Japan and Guidelines for Iran aging strategic plan. Journal of aging. 2007; 2(3): 166-76.

[3] Statistical Center of Iran. Statistical year book. Available from: https://www.amar.org.ir/

[4] Yousefi H, Abedi HA, Yarmohammadian MH, Elliott D. Comfort as a basic need in hospitalized patients in Iran: a hermeneutic phenomenology study. Journal of advanced nursing. 2009 Sep;65(9):1891-8.

[5] Ghazi Moradi Hassan, Work and Leisure in Iranian people.Ame Press. Tehran. 2012

[6] Abedi H, Lali M, Keyvanniya S, Nikbakht A. Life experiences of older people who are used to spend their time in parks. Journal of Qualitative Research in Health Sciences. 2013 Jul 15;2(2):184-93.

[7] Lampinen P, Heikkinen RL, Kauppinen M, Heikkinen E. Activity as a predictor of mental well-being among older adults. Aging and mental health. 2006 Sep 1;10(5):454-66.

[8] Chang PJ, Wray L, Lin Y. Social relationships, leisure activity, and health in older adults. Health Psychology. 2014 Jun;33(6):516.

[9] Menec VH. The relation between everyday activities and successful aging: A 6-year longitudinal study. The Journals of Gerontology Series B: Psychological Sciences and Social Sciences. 2003 Mar 1;58(2):S74-82.

[10] Lee HY, Yu CP, Wu CD, Pan WC. The effect of leisure activity diversity and exercise time on the prevention of depression in the middle-aged and elderly residents of Taiwan. International journal of environmental research and public health. 2018 Apr 1;15(4):654.

[11] Heesch KC, Van Uffelen JG, van Gellecum YR, Brown WJ. Dose-response relationships between physical activity, walking and health-related quality of life in mid-age and older women. J Epidemiol Community Health. 2012 Aug 1;66(8):670-7.

[12] Wolin KY, Glynn RJ, Colditz GA, Lee IM, Kawachi I. Long-term physical activity patterns and health-related quality of life in US women. American journal of preventive medicine. 2007 Jun 1;32(6):490-9.

[13] Barcelos-Ferreira R, Nakano EY, Steffens DC, Bottino CM. Quality of life and physical activity associated to lower prevalence of depression in community-dwelling elderly subjects from Sao Paulo. Journal of affective disorders. 2013 Sep 5;150(2):616-22.

[14] Wada K, Satoh T, Tanaka K, Tsunoda M, Aizawa Y. Associations of depressive symptoms with regular leisure activity and family social support among Japanese workers. Industrial health. 2007;45(1):181-5.

[15] Wakui T, Saito T, Agree EM, Kai I. Effects of home, outside leisure, social, and peer activity on psychological health among Japanese family caregivers. Ag- 
ing \& mental health. 2012 May 1;16(4):500-6.

[16] Li Y, Ferraro KF. Volunteering and depression in later life: Social benefit or selection processes?. Journal of Health and Social Behavior. 2005 Mar;46(1):68-84.

[17] Islami A, Vakili Mohammad A, Faraji J. Depression rate in medical students of Gorgan University of Medical Sciences and its relation with how to spend leisure time.2002;4(9):52-59.

[18] HazarJaribi J, Arfee E R. Leisure time and social health.Social Development and Welfare Planning.2011;10:39-63.

[19] Rahimi A, Ahmadi F, Foroughan M. Experience of elderly in leisure and recreation. Journal of Aging. 2010;5(1):61-77.

[20] Likert R. A technique for the measurement of attitudes. Archives of psychology. 1932.

[21] Seyfzadeh A, Hagighatian M, Mohajerani A. The Relationship Between Social Isolation and Health Among the Tehranian Elderly. J Educ Community Health. 2017 Dec 15;4(3):20-8.

[22] Nagi SZ. An epidemiology of disability among adults in the United States. The Milbank Memorial Fund Quarterly. Health and Society. 1976 Oct 1:439-67.

[23] Sadat Madhad S B, Imami A, Mahdi P, Foroughan M, Nowruz Tabriz K, Mohammadi F, Mazaheri M. The status of social activities and leisure in the elderly of Iran and Sweden. Iranian Journal of Ageing.2009;3(8):597-606

[24] Triadó C, Villar F, Solé C, Celdrán M, Osuna MJ. Daily activity and life satisfaction in older people living in rural contexts. The Spanish journal of psychology. 2009 May;12(1):236-45.

[25] Melzer I, Benjuya N, Kaplanski J. Effects of regular walking on postural stability in the elderly. Gerontology. 2003;49(4):240-5.

[26] Lee JH, Lee JH, Park SH. Leisure Activity Participation as Predictor of Quality of Life in Korean Urban dwelling Elderly. Occupational therapy international. 2014 Sep;21(3):124-32.

[27] Cheung MC, Ting W, Chan LY, Ho KS, Chan WM. Leisure participation and health-related quality of life of community dwelling elders in Hong Kong. Asian Journal of Gerontology and Geriatrics. 2009 Jun;4(1):15-23.

[28] Norouzi, K. Design, implementation and evaluation of a care model on the community of elderly people living in Tehran. PhD thesis, Faculty of Medicine, TarbiatModarres University, 2006

[29] Paillard-Borg S, Wang HX, Winblad B, Fratiglioni L. Pattern of participation in leisure activities among older people in relation to their health conditions and contextual factors: a survey in a Swedish urban area. Ageing \& Society. 2009 Jul;29(5):803-21.

[30] Conde MD. Leisure patterns and needs of the elderly in rural Galicia (Spain). Educational Gerontology. 2012 Feb 1;38(2):138-45.

[31] Krantz-Kent R, Stewart J. How do older Americans spend their time. Monthly Lab. Rev. 2007; 130:8.
[32] Tessier S, Vuillemin A, Bertrais S, Boini S, Le Bihan E, Oppert JM, Hercberg S, Guillemin F, Briançon S. Association between leisure-time physical activity and health-related quality of life changes over time. Preventive medicine. 2007 Mar 1;44(3):202-8.

[33] Deslandes A, Moraes H, Ferreira C, Veiga H, Silveira H, Mouta R, Pompeu FA, Coutinho ES, Laks J. Exercise and mental health: many reasons to move. Neuropsychobiology. 2009;59(4):191-8.

[34] SHahbazi MR, Mirkhani M, Hatamizadeh N, RahgozarM.Eveluetion of disability in the elderlyinTehran. Journal ofSalmand.2008; 3(9):84-92.

[35] Marquezs, Garatachea N, Molinero O, MartínezGarcía R, Jimenez-Jimenez R, Gonzalez-Gallego J,. Feelings of well being in elderly people: relationship to physical activity and physical function. Archives of Gerontology and Geriatrics. 2009 May 1;48(3):30612.

[36] Holstila A, Mänty M, Rahkonen O, Lahelma E, Lahti J. Changes in leisure time physical activity and physical and mental health functioning: a followup study. Scandinavian journal of medicine \& science in sports. 2017 Dec;27(12):1785-92. 